\title{
Ja, ucieleśniona w ruchu, czyli o biegowej drodze z autoetnografią
}

\author{
Karolina Szyma-Ziembińska \\ Uniwersytet Warszawski
}

DOI: http://dx.doi.org/10.18778/1733-8069.17.1.04

\section{Słowa kluczowe: antropologia sportu, antropologia ciała, ucieleśnienie, autoetnografia, bieganie}

\begin{abstract}
Abstrakt: Artykuł pokazuje, w jaki sposób autoetnografia może wzbogacić badania nad sportem. Na podstawie swoich doświadczeń jako byłej biegaczki wyczynowej autorka opisuje, w jaki sposób wykorzystała narzędzia takie jak: film autoetnograficzny, fotografia czy dziennik badawczy do kompleksowego antropologicznego opisu zmysłowego doświadczenia biegu. Badaczka obserwuje poszerzający się zakres wykorzystania autoetnografii w różnorodnych tematach badawczych ze szczególnym pochyleniem się nad antropologią ciała. Mierzy się z problemem językowej niewyrażalności doświadczenia ciała w sporcie i proponuje własne rozwiązania. Tekst został napisany na podstawie książki Ucieleśnione w ruchu. Polskie biegaczki wyczynowe w perspektywie antropologicznej oraz uzupełniony o nowe spostrzeżenia. Jak pisze autorka: „Autoetnografia ma dla mnie wartość również w tym sensie, że jest ciekawą konfrontacją rozmówców z badaczem, podczas której zachodzi wymiana doświadczeń i opinii. Jest to swego rodzaju praca nad relacją. W ten sposób obie strony się odsłaniają, obie coś ryzykują, a to może prowadzić do ciekawych wniosków" (Szyma 2019: 32).
\end{abstract}

Karolina Szyma-Ziembińska, mgr, antropolożka kulturowa i historyczka sztuki, absolwentka Instytutu Etnologii i Antropologii Kulturowej Uniwersytetu Warszawskiego oraz Wydziału Zarządzania Kulturą Wizualną Akademii Sztuk Pięknych w Warszawie. Zajmuje się antropologią sportu i ciała, Gender Studies oraz sztuką w ujęciu instytucjonalnym. Autorka książki (2019) Ucieleśnione w ru- chu. Polskie biegaczki wyczynowe w perspektywie antropologicznej, Warszawa: WUW.

\section{Adres kontaktowy:}

Instytut Etnologii i Antropologii Kulturowej UW

ul. Żurawia 4, 00-503 Warszawa

e-mail: szyma.karolina@gmail.com 
wprawiłam się w ruch wystawiłam blady policzek podmuch + gęsia skórka z biegiem czasu nastapita zmiana wewnatrz ciała wszystko sprężyste_przejrzyste ruch ustat, policzek spieczony

[Szyma 2018]

\section{Dlaczego warto badać sport autoetnograficznie?}

W swoich notatkach Bronisław Malinowski napisał:

Trzeba się bardziej interesować innymi, a nie sobą tylko o tyle, o ile ci inni wydają się usprawiedliwieni w interesowaniu się bardziej sobą niż tobą: szanuj osobowość każdego, nigdy nie kłopocz się życiem innych i twórz tak i w takiej jakości i formie, aby wzbogacało życie innych, jak i twoje. (2008: 664)

Taki sposób ujęcia relacji między badanym a badaczem jest dla mnie kwintesencją podejścia autoetnograficznego, które staje się coraz częściej wykorzystywaną metodologią w badaniach społecznych.

Mniej więcej w tym samym czasie, kiedy Malinowski pisał swoje słynne dzienniki, po drugiej stronie oceanu socjolog Robert Park zainspirował wielu ze swoich studentów Uniwersytetu Chicago do zainteresowania się badawczo obszarami im bliskimi, w których na co dzień żyli. Jednak dopiero w 1979 roku antropolog David Hayano opublikował esej autoetnograficzny, w którym opisał korzyści płynące $\mathrm{z}$ samoobserwacji $\mathrm{w}$ badaniach etnograficznych. Jedną z nich było odejście od badań uprawianych w kolonializmie i zwrot ku samemu sobie

- zainteresowanie swoim światem społecznym
(Anderson 2014). Właściwe powstanie i nazwanie autoetnografii dokonało się dzięki Carolyn Ellis, której poglądy na temat badań społecznych oraz trudna sytuacja życiowa doprowadziły do pogłębionego autoetnograficznego opisu swoich przeżyć (Kafar 2014). Razem z Arturem Bochnerem w 2000 roku w zbiorze tekstów The Handbook of Qualitative Research opublikowali rozdział pod tytułem Autoethnography, personal narrative, reflexivity: Researcher as subject.

W ostatnich latach badacze szczególnie często odwołują się do subiektywizmu patrzenia na świat pojedynczego uczestnika badanej grupy, co zostało zintensyfikowane przez „postmodernistyczny zwrot w humanistyce, który zrelatywizował dotychczasowe schematy wytwarzania wiedzy, wskazując na ich względność" (Kacperczyk 2014: 36). Na znaczeniu zyskało wszystko to, co subiektywne i indywidualne. Nastąpił „zwrot ku jednostce - usytuowanej, ucieleśnionej, osadzonej w miejscu i czasie, skontekstualizowanej, o niepowtarzalnej biografii" (Kacperczyk 2014: 66). Autoetnografia stała się metodą wspierającą takie podejście.

Z biegiem czasu badacze coraz chętniej zaczęli odwoływać się do podejścia autoetnograficznego. Co jednak warte podkreślenia, staje się to niekiedy jedynie błędnym przyczynkiem do skupienia się na samym sobie przez badacza. Złożona natura podejścia autoetnograficznego prowadzi często do błędnych uproszczeń i skrótów myślowych. Bywa, że metoda ta ulega wypaczeniu i traktowana jest wymiennie lub jednocześnie jako:

1. akt autonarracji;

2. dokument stworzony przez narratora, czyli produkt utrwalenia autonarracji; 
3. technika otrzymywania danych, czyli wyprodukowanie opisu autoetnograficznego i poddanie go analizie;

4. całościowa strategia badawcza, polegająca na długoterminowej autoobserwacji i relacjonowaniu jej w założony przez siebie sposób;

5. nowatorski wzorzec uprawiania nauki w polu nauk społecznych (Kacperczyk 2014).

Niejasności pojawiają się również przy podziale samej autoetnografii na różne rodzaje. Mamy bowiem do czynienia z dwiema głównymi odmianami autoetnografii: autoetnografią ewokatywną oraz autoetnografią analityczną. Pierwsza została wprowadzona do badań przez Carolyn Ellis. W tym wariancie autoetnografia uznawana jest za nowy wzorzec uprawiania nauki, w którym teksty pisane są z reguły w pierwszej osobie i przybierają różnorodną postać, sięgając po odmienne techniki literackie (Kacperczyk 2014). Punktem wyjścia staje się doświadczenie (najczęściej trudne) badacza, które ma wywołać w czytelniku silne emocje. Cechą charakterystyczną jest tutaj pisanie narracyjne (Kacperczyk 2014), przez co zaciera się silna granica między etnografią a biografią, a sposób opowiadania może przypominać nawet powieść. Nie same wnioski są tutaj najważniejsze, ale przebyta w tekście droga (Ellis, Bochner 2000). Eksplorowane są tematy o dużym ładunku emocjonalnym: choroba, strata, śmierć, katastrofa czy rozwód, by wpłynąć na czytelnika, wzbudzić u niego emocje (Kacperczyk 2014).

Autoetnografia analityczna, postulowana między innymi przez Leona Andersona, odwołuje się natomiast do pojmowania jej jako metody i strategii badawczej. Nawiązuje ona do klasycznej etnografii, w przypadku której dokonuje się realistycznego opisu rzeczywistości, z licznymi uwagami i spostrzeżeniami badacza będącego uczestnikiem danej rzeczywistości (Kacperczyk 2014). Anderson wymienia pięć cech proponowanej autoetnografii:

1. pełne uczestnictwo badacza w badanym środowisku;

2. refleksyjność analityczna;

3. obecność własnego Ja badacza w narracji;

4. dialog z innymi informatorami niż Ja badacza;

5. zaangażowanie $\mathrm{w}$ analizę teoretyczną (Anderson 2014: 149).

Można zatem powiedzieć, że autoetnografia analityczna jest próbą pogodzenia w badaniach podejścia naukowego oraz autorefleksyjnego, gdzie „[w]łasnego narracyjnego Ja używa [się], aby zrozumieć i opisać świat innych" (Kacperczyk 2014: 46). Przeżycie samo w sobie nie jest tutaj kluczowe - najważniejsza jest natomiast stworzona na podstawie doświadczenia wiedza (Kacperczyk 2014). Na potrzeby swojego badania wybrałam właśnie podejście analityczne, ponieważ zależało mi na rzetelności naukowej i pozostawieniu badanych biegaczek w centrum uwagi, przy jednoczesnym silnym zaznaczeniu obecności mnie jako badaczki i biegaczki.

Nowoczesne podejście w antropologii wyrosło, po pierwsze, $z$ wcześniej wspomnianego humanistycznego zwątpienia $\mathrm{w}$ możliwość prowadzenia obiektywnych badań oraz, po drugie, z przewrotu performatywnego, który wzbudził zainteresowanie sprawczością (ang. agency) bytów ludzkich, ale i zwierząt oraz bytów nieożywionych (rzeczy materialne) (Domańska 2007). W podejściu tym chodzi o realne działanie, na którym zasadza się performatywne podejście do uprawiania autoetnografii. Zakłada to specjalny rodzaj autoprezentacji, użycie konkretnych środków artystycznych przed widownią czy kreowanie ucieleśnionego doświadczenia (Kacperczyk 2014). 
Innym podejściem jest autoetnografia kolaboratywna, polegająca na obserwowaniu Ja badacza przy jednoczesnym dzieleniu się swoimi spostrzeżeniami ze współbadaczami. Pozwala to na większą wydajność oraz wzbogacenie badań o wspólną eksplorację własnego doświadczenia (Chang, Ngunjiri, Hernandez 2013).

Świadomość wyboru konkretnego podejścia autoetnograficznego wydaje się szczególnie ważna dla tekstu. Inaczej skonstruowany będzie bowiem taki, w przypadku którego sięgamy po autoetnografię analityczną, a inaczej ewokatywną. Jednocześnie badacze urozmaicają swoją metodologię, korzystając z elementów performatywnych i kolaboratywnych.

W przypadku badań nad biegaczkami zdecydowałam się na podejście analityczne, które łączy w sobie naukowe podejście do badanego zagadnienia z autorefleksyjnym osadzeniem siebie jako badacza w badanym środowisku. Dlaczego jednak ogólnie wybrałam właśnie autoetnografię do badania badaczek wyczynowych? W pierwszej kolejności wynika to ze stosunku emocjonalnego i czynnego zaangażowania w badane środowisko - jego działania i sposób patrzenia na świat, które są mi bliskie. Po drugie, mam wrażenie, że niemożliwe są dzisiaj badania zjawisk związanych z cielesnością bez udziału własnego - pisanie o ciele konkretnej drugiej osoby i pisanie o ciele w ogóle wymaga własnego doświadczenia. Po trzecie, ciało badacza jest widoczne i nieuniknione, a autoetnografia pozwala prawdopodobnie na jego trafniejszą konceptualizację oraz lepsze uzasadnienie niektórych hipotez. Autoetnografia ma dla mnie wartość również w tym sensie, że jest ciekawą konfrontacją rozmówców z badaczem, podczas której zachodzi wymiana doświadczeń i opinii. Jest to swego rodzaju praca nad relacją. $W$ ten sposób obie strony się odsłania- ją, obie coś ryzykują, a to prowadzić może do ciekawych wniosków. Autoetnografię rozpatrywać jednak można również na bardziej podstawowym poziomie - jako rozpoczęcie dialogu z samym sobą i swoim doświadczeniem, które staramy się opisać, skonceptualizować i obejrzeć z innej perspektywy.

Jeżeli prawdą jest, że „poznać oznacza poddać się zjawisku, a nie myśleć o nich z wyżyn dystansu" (Taussig 1992: 10), to poznanie świata zakłada istnienie podmiotu, który pragnie przekroczyć własny wewnętrzny dialog intelektu. Niezależnie od tego, czy planujemy poznanie konkretnego świata w sposób praktyczny, czy teoretyczny, możemy oddać się mu jedynie za pomocą nas samych. (Hastrup 2008: 85)

Dialog może zachodzić w różnych sferach, ale dla mnie najważniejsza była dyskusja z własnym ciałem oraz własnymi emocjami, które często pozwalają wrócić pamięcią do pewnych wydarzeń i odtworzyć szczegóły (McMahon 2011).

\section{Dlaczego warto sięgać po różne narzędzia?}

\section{Kontekst}

Jako jedenastolatka zaczęłam regularne treningi w klubie lekkoatletycznym w Warszawie. Przez osiem lat sześć razy w tygodniu biegałam pod czujnym okiem trenera. Moje ciało zmieniało się pod wpływem uprawianego sportu, co niejednokrotnie dostrzegałam, kiedy porównywałam się z nietrenującymi rówieśniczkami. W szkole stykałam się z prześmiewczymi komentarzami dotyczącymi moich mięśni nóg i ramion. Częste treningi sprawiały również, że noszenie makijażu czy staranne układanie włosów nie miało większego sensu. Wyglądałam więc nieco inaczej niż pozostałe dziewczęta 
w moim wieku. Miało to też jednak oczywiście dobre strony. Jako osoba silniejsza i bardziej wytrzymała fizycznie czułam się samodzielna. Trenowanie miało też rzecz jasna wpływ na moją kondycję psychiczną - miałam mniej czasu na rozwijanie swoich innych pasji i na naukę, ale dość dobrze radziłam sobie ze stresem. Wraz z pójściem na studia postanowiłam zakończyć profesjonalną karierę sportową. Bieganie pozostało jednak moją pasją, która ewoluowała przez lata. Dwukrotnie ukończyłam maraton i startowałam w wielu krótszych biegach ulicznych.

\section{Niewyrażalność i kobiecość - problem badawczy}

Moje wieloletnie i zróżnicowane doświadczenie skłoniło mnie do głębszej refleksji nad kulturowym aspektem kształtowania ciała poprzez bieganie wyczynowe. Rozpoczęłam swoje badania od przeprowadzenia trzech wywiadów z mężczyznami, którzy zwrócili uwagę na takie aspekty jak: samodyscyplina, życiowe wybory, sport wyczynowy a rekreacyjny. Rozmowy okazały się bardzo ciekawe, jednak moja badawcza intuicja podpowiadała mi, że brakuje $\mathrm{w}$ tym miejscu jakiegoś ważnego wymiaru. Po pierwszej rozmowie z kobietą-biegaczką już wiedziałam, że chodzi o ujęcie genderowe, które szybko stało się głównym tematem mojego projektu. Od tej pory ograniczyłam się do wywiadów jedynie z biegaczkami, poszukując równolegle w dzienniku badawczym notatek, które odnosiłyby się wprost lub pośrednio do mojej płci i problemów z nią związanych.

Jednocześnie zdałam sobie sprawę, że dość rzadko mówi się o sporcie jako silnym doświadczeniu zmysłowym. Ponadto po przeprowadzeniu kilku wywiadów z koleżankami ze środowiska biegowego okazało się, że mówienie o doświadczaniu własnego ciała jest niezwykle trudne - niekoniecz- nie dlatego, że jest to wstydliwe lub intymne, lecz z powodu niemożności znalezienia odpowiedniego języka opisu. Opowiadanie przychodzi z łatwością, dopóki wspomina się biegowe początki lub opowiada o marzeniach i planach. Trudności pojawiają się, kiedy następuje próba opisania, wydawać by się mogło, najprostszej i najbardziej podstawowej kwestii - jak czuje się kobieta, kiedy biegnie? Nieco łatwiej mówi się o ciele w trakcie kontuzji, bo tutaj właściwie jedynym sposobem opisu jest sięgnięcie po terminologię medyczną lub czysto anatomiczną. Trudno opowiada się o samopoczuciu biegaczki (a mowa tutaj o takich odczuciach jak: zmęczenie, ból, trudność ruchu czy znużenie), kiedy siedzi się w wygodnym fotelu w kawiarni lub na łóżku przed komputerem. Problem z opisem tkwi w tym, że bieganie profesjonalne jest rodzajem wiedzy pozadyskursywnej lub inaczej wiedzy milczącej (ang. tacit knowledge), którą „trudno zwerbalizować i jest ona nabywana przede wszystkim poprzez doświadczenie. Jest ona opisywana jako know-how (wiedzieć jak), w przeciwieństwie do wiedzy know that (wiedzieć, że)" (Jakubowska 2015: 174).

Swoista „niewyrażalność” (spowodowana tym, że niektóre umiejętności czy aktywności jeszcze nigdy nie zostały nazwane) sprawiła, że wiedza pozadyskursywna do dziś traktowana jest w badaniach społecznych po macoszemu. Nie ufamy bowiem temu, czego nie jesteśmy w stanie zakomunikować, szczególnie w obszarze nauki. Konstruktywizm sprawił również, że nie wierzymy w istnienie czegoś, dopóki nie będzie to miało swojego odzwierciedlenia $\mathrm{w}$ kulturze, a szczególnie $\mathrm{w}$ języku (Jakubowska 2015). W tym sensie bieganie idealnie wpisuje się w tak zwany "schemat cielesny", który rozumiany jest jako „włączone cielesne (incorporated bodily) know-how i praktyczny sens: perspektywistyczne zrozumienie świata «z punktu widze- 
nia ciała». Oznacza to, że osoba «wie, nie wiedząc» (knows without knowing)" (Jakubowska 2015: 179), jak wykonywać konkretne czynności.

Mówienie i pisanie o ruchu cielesnym przysparza wielu problemów (Samudra 2008) obserwatorowi zewnętrznemu, a co dopiero osobie próbującej opisać własny ruch i odczucia z nim związane.

Traktowanie słów jako uprzywilejowanego klucza do tożsamości, historii, społeczeństwa czy kultury jest epistemologicznym błędem. Tożsamości przechowywane są w praktyce; to habitus konkretnego ludu jest podstawą tej pozbawionej intencji konwencji zgodnego z regułami improwizowania, które nadaje pewną spójność ich światu (Bourdieu 1977: 79). Same słowa są tylko ograniczonym środkiem dostępu do tego świata. (Hastrup 2008: 54)

Już w samych badaniach antropologicznych przez dekady skupiano się na języku i świadomości, pomijając sprawy związane stricte $\mathrm{z}$ ciałem (Samudra 2008), które przez swoją fizyczność i wizualność jest proste do ogarnięcia wzrokiem oraz zrozumienia często demonstrujemy coś za pomocą ruchów. Tak jest chociażby w przypadku ćwiczeń gimnastycznych, które pokazuje i jednocześnie nazywa wuefista. Po ukończeniu szkoły znamy pewne ćwiczenia, ale nie do końca potrafimy je opisać. Nazwanie części ciała oraz przypisanie do niej konkretnej aktywności, takiej jak „,kopnięcie”, „machnięcie”, „,uderzenie" czy „zgięcie”, nie zawsze wystarcza.

Na jednym z ostatnich treningów, który odbywałam razem z koleżanką, trener polecił zrobienie znanego nam dobrze wieloskoku (opisywanego zazwyczaj jako „bardzo mocny wyrzut biodra i bardzo mocne wybicie"), ale na jednej nodze i w górę. Usiłowałyśmy zrozumieć, o które ćwiczenie może trenerowi chodzić, bezskutecznie wykonując wiele wariacji na temat zadanego nam wieloskoku. W końcu zrezygnowane zaczęłyśmy podskakiwać z jednoczesnym uderzaniem piętą o pośladek. Udało się! Nadal nie rozumiałyśmy jednak, dlaczego trener skojarzył te dwa typy ćwiczeń. Wynikać to może z faktu, że kulturowa wiedza ludzi specjalizujących się w technikach cielesnych (a szczególnie w sporcie, jakim jest bieganie) jest tak głęboko ucieleśniona, że z reguły nieprzekładalna na kod semiotyczny (Samudra 2008).

Podobne problemy pojawiają się, kiedy biegaczki, z którymi rozmawiałam, usiłowały opowiedzieć mi o reakcji ciała na pewne ćwiczenia lub aktywności. Większość wykonywanych ruchów w sporcie powinna wręcz stać się nawykami, nad którymi człowiek nie powinien się zastanawiać.

Świadomość przy budowaniu ucieleśnionych nawyków biegowych podzielić można na trzy kategorie: ucieleśnioną, praktyczną i dyskursywną (Jakubowska 2015). Wszystkie biegaczki mają tę pierwszą, ponieważ potrafią zapanować nad ciałem w momentach kryzysowych i dobrze wiedza, jak je trenować, żeby osiągać sukcesy, ale często nie wiedzą, jak werbalnie wyrazić to, co „wiedzą" na temat chociażby swoich ruchów biegowych - łatwiej jest im je pokazać, niż opisać słowami. Jest to „wiedza jak”, specyficzna dla konkretnego działania (Jakubowska 2015). Drugi typ świadomości, „wiedzę praktyczną, czyli milczące informacje, kompetencje, know-how zyskujemy poprzez relacje z kulturą materialną, na przykład z przedmiotami, które instruują nas, jak ich używać, a środkiem jej zdobywania jest praktyka" (Jakubowska 2015: 181). Zawodniczki uczą się jej poprzez korzystanie z różnego rodzaju sprzętu i przedmiotów przeznaczonych do treningu - przyrządów na siłowni czy butów-kolców do biegania. 
Świadomość dyskursywna jest rzadsza, bo teoretyczna, choć zdarza się na przykład u zawodniczek studiujących kierunki związane z cielesnością, takie jak medycyna, fizjoterapia czy weterynaria.

Wydaje się, że to właśnie próba opisania samego biegu jako czynności, o której trudno się opowiada, stała się dla mnie największym wyzwaniem. Moment przełamania nastąił, kiedy postanowiłam opisać bieganie przez pryzmat zmysłów, co rozwinę w dalszej części tego tekstu.

\section{Metodologia}

Rozważania tego typu zaprowadziły mnie do przygotowania wstępnych hipotez i pytań badawczych:

- Jak zawodniczka odczuwa zmysłowo bieganie?

- Jak antropologicznie można ująć budowanie biegowej wytrzymałości?

- Jak realizowana jest „pamięć ciała” przez biegaczki?

- Jak wygląda dyscyplina ciała u polskiej biegaczki wyczynowej?

- Jacy ważni aktorzy społeczni mają wpływ na kształtowanie się cielesności biegaczki?

- W jaki sposób kształtuje się cielesna kobiecość u biegaczek?

- Gdzie leży sprawczość biegaczki wyczynowej?

Następnie przeprowadziłam badania terenowe, w tym 16 wywiadów etnograficznych z zawodniczkami wyczynowymi, czyli takimi, które trenują codziennie, startują w zawodach i osiągają sukcesy co najmniej na arenie narodowej (medalistki mistrzostw Polski). Najlepsze z nich startują na imprezach międzynarodowych, takich jak mistrzostwa świata czy igrzyska olimpijskie. Nie wszystkie moje rozmówczynie należą do kadry narodowej i mają swojego sponsora, niemniej jednak bieganie jest dla nich źródłem mniejszych bądź większych zarobków. Rozmawiałam najczęściej przez Skype'a, czasem na żywo w kawiarni. Korzystałam z wcześniej przygotowanego przeze mnie scenariusza wywiadu. Pytania zadawane biegaczkom miały charakter głównie pomocniczy, ponieważ każda rozmowa przebiegała swobodnie i naturalnie. Podczas analizy materiału wyodrębniłam dwie uzupełniające się perspektywy - wewnętrzną i zewnętrzną.

\section{Perspektywa wewnętrzna/zmysłowa}

Pierwsza dotyczyła zmysłów i tego, w jaki sposób bieganie jest odczuwane wewnętrznie i subiektywnie przez zawodniczki. Tę część podzieliłam na kilka podrozdziałów odnoszących się kolejno do poszczególnych zmysłów. Problematyczność opowiadania o reakcjach własnego ciała sprawiła, że wypowiedzi na ten temat pojawiały się jakby przy okazji i nieczęsto, stąd w tej części pojawiło się mniej cytatów z wywiadów, a więcej wniosków z obserwacji oraz autoetnografii.

Bieganie jest aktywnością wytwarzającą specyficzny rodzaj przestrzeni społecznej (Lefebvre 1991), ponieważ bardzo często miejsca, w których wykonuje się trening, są wspólne dla wielu biegaczy i biegaczek. Dotyczy to szczególnie stadionów lekkoatletycznych, ale również popularnych parków, dzielnic lub miejscowości na całym świecie słynących ze świetnych warunków do treningu biegowego. Ścieżki biegowe tworzone są na dwa sposoby. Po pierwsze, poprzez ich popularność wśród biegaczek oraz częste korzystanie $z$ nich podczas różnych aktywności. Po drugie, przez wyobrażenia społeczne na ich temat, a więc tworzenie reprezentacji owych przestrzeni: myśli, pomysłów, opowieści i wspomnień uczestników (Hockey 2006). Poprzez „ży- 
wość" takich miejsc (Lefebvre 1991) produkowane są zatem specyficzne formy wiedzy cielesnej. Praktykowanie przestrzeni odbywa się przy udziale wszystkich zmysłów, które informują biegaczkę, w jaki sposób powinna lub ma możliwość się w niej poruszać. Zmysły pomagają więc również w zorientowaniu się, jak biegać, pomagają ten bieg ucieleśnić i uczą, jak dokonywać wyborów cielesnych. Bieganie jest zatem aktywnością realizowaną z udziałem wszystkich zmysłów (Hockey 2006). Jak twierdzi Honorata Jakubowska: „Wiedza sensoryczna, którą nabywa sportowiec, staje się częścią wiedzy ucieleśnionej i jako taka ma pozadyskursywny charakter" (2015: 179).

Mimo że dla porządku wyodrębniłam poszczególne zmysły, jednocześnie podkreśliłam, że doświadczenie biegowe traktuje jako intensywnie zachodzącą synestezję, czyli równoczesne postrzeganie wieloma zmysłami.

W antropologii synestezja jest rozumiana nie tyle jako szczególna zdolność wybranych jednostek, co jako wielozmysłowy sposób doświadczania rzeczywistości cechujący nas wszystkich. Zjawisko synestezji najłatwiej wyjaśnić na przykładzie jedzenia. Barbara Kirshenblatt-Gimblett pisze: „Na podstawie koloru, temperatury, połysku i tekstury wnioskujemy o smaku i zapachu potraw. Poprzez to, jak rzeczy wyglądają, jak układają się w dłoniach, jak pachną i brzmią (skwierczą, bulgoczą, chrupią), potrafimy odróżnić dobrą potrawę od złej, określić jakość produktów. Nasze oczy pozwalają nam smakować z dystansu, a znajome kolory i kształty pobudzają pamięć sensoryczną doświadczanych już niegdyś smaków, zapachów, tekstur". (Wala 2012)

Doświadczenie biegowe zachodzi przy równoczesnym udziale zmysłów: propriocepcji (odczuwa- nie napięcia mięśniowego oraz ułożenia części ciała wobec siebie), nocycepcji (zmysł bólu), zmysłu równowagi oraz prawdopodobnie wielu innych. W tej części starałam się opisać zatem bieg z perspektywy: ruchu, wzroku, słuchu, węchu, smaku i dotyku. Ważne było również odczuwanie temperatury.

\section{Perspektywa zewnettrzna/medialno-wizualna}

Druga część dotyczyła natomiast spojrzenia zewnętrznego, czyli tego, w jaki sposób moje rozmówczynie są postrzegane przez otoczenie, jak ono na nie wpływa oraz jaką dyscyplinę tworzy. $W$ większości przypadków nikt nie ma bowiem wątpliwości, że dana biegaczka ,jest kobietą”. Kanony piękna w lekkoatletyce nie są konkretnie określone, toteż rzadko dochodzi do konfliktów na tym tle, podczas gdy w innych dziedzinach (nawet w obrębie innych dyscyplin sportu) mamy do czynienia na przykład z dyskryminacją rasową lub wiekową.

Z drugiej strony większość biegaczek jest uważanych za atrakcyjne, ponieważ „[k]ultura zachodu określana jest mianem kultury młodości, w której liczy się fizyczność bez skazy, [...] [gdzie n]a każdym kroku kobiety są nawoływane do intensywnej pracy nad własnym ciałem" (Garncarek 2010: 61). Biegaczki, trenujące swoje ciała każdego dnia, idealnie wpisują się w dzisiejsze kanony kobiecego piękna: mają płaskie, wyrzeźbione brzuchy, szczupłe i silne nogi, umięśnione (ale koniecznie nie za bardzo!) plecy. Zbudowane w ten sposób ciało jest oczywiście wynikiem ciężkiego treningu i wszystkiego, co z nim związane, ale dyskurs zbudowany wokół niego jest z reguły męski - „[p]erspektywa, z której odbywa się samokontrola, jest perspektywą «męskiego oka», ciało kobiety jest projektem męskim" (Garncarek 2010: 65). 
Komentatorami imprez biegowych przy okazji transmisji telewizyjnej w Polsce są zawsze mężczyźni. O ile do prezentowania wiadomości sportowych $\mathrm{w}$ ramach codziennego dziennika telewizyjnego włączono również kobiety, o tyle komentowanie zawodów wciąż pozostaje domeną typowo męską. Podobnie jest $\mathrm{w}$ przypadku sportowego dziennikarstwa prasowego, gdzie dominują mężczyźni w 2011 roku tylko 8 procent artykułów wyszło spod ręki kobiet (Jakubowska 2012). To z męskiej perspektywy opisywana była między innymi sprawa wcześniej przywołanej Caster Semenyi podczas igrzysk olimpijskich w Rio de Janeiro w 2016 roku.

Przed biegiem dziennikarze prezentują zawodników i zawodniczki, którzy za chwilę wystartują. Podczas gdy o wyglądzie męskich ciał nie wspominają niemalże w ogóle, o kobiecych mówią chętnie i często. "Świetne warunki fizyczne”, "posągowa figura”, „długie nogi jak u gazeli”, „piękna uroda” - to tylko niektóre określenia odwołujące się do wyglądu biegaczek startujących w zawodach.

Innym ważnym głosem osądzającym cielesność biegaczki jest głos trenera - częściej męski niż kobiecy. To właśnie on jest osobą, która w dużej mierze decyduje, jaki rodzaj treningu wykona biegaczka, ale niekiedy ingeruje również $\mathrm{w}$ jej dietę, a pośrednio nawet - wygląd. W środowisku biegowym bycie szczupłą oznacza najczęściej bycie akceptowaną (McMahon 2011).

Zewnętrzny ogląd dyscyplinowania biegaczki oraz nierówności $\mathrm{w}$ obrazie medialnym kobiet i mężczyzn w tym środowisku zestawiłam ze spojrzeniem własnym biegaczek - $\mathrm{w}$ jaki sposób same budują swoją biegową sprawczość. Tworzona jest na kilku polach: w obszarze mówienia otwarcie o fizycznych mankamentach swojego wyglądu czy o menstruacji. Problemy zdrowotne lub mankamenty wyglądu biegaczki uznają bowiem za coś, co je uczłowiecza.

To tutaj tworzy się sprawczość cielesna i brzmieć może: „Jestem biegaczką i jestem kobietą - to ludzkie, że chcę osiągać dobre wyniki sportowe, ale równocześnie czuć się dziewczyną: z miesiączką, fizycznymi kompleksami i naturalną dietą". To podejście do kobiecej fizjologii biegaczek uznane może być za odwrotne $\mathrm{w}$ stosunku do tego dotyczącego kobiet niesportsmenek. W przypadku tych drugich często mówi się, że miesiączkowanie jest niesprawcze, ponieważ przeszkadza kobiecie i pojawia się często wbrew jej woli. Biegaczki natomiast mówią o miesiączce $\mathrm{w}$ kategoriach wyboru i panowania nad ciałem: „To ja decyduję, kiedy mam okres”. Ponadto pojawienie się miesiączki uważane jest za sprawcze, ponieważ jest czymś pożądanym i „naturalnym" (w pozytywnym tego słowa znaczeniu).

Sport powszechnie kojarzony jest z cyborgizacją ciała ludzkiego, a jednak sposób, w jaki wypowiadały się moje rozmówczynie, wskazuje na jej zaprzeczenie. Ma się nawet wrażenie, że wiele rzeczy przychodzi niejako „przy okazji”. Wykonując ciężki trening, nie mówi się o swoich porażkach czy rutynie ze łzami w oczach - to taka swoista "staranna niedbałość". Wykonują treningi, ale sięgają właściwie tylko po stoper, rezygnując z wszelkich nowych technologii, uważając, że dostatecznie dobrze znają swoje organizmy i ufają im.

\section{Narzędzia wspomagające}

Poniżej opiszę również przykładowe inne narzędzia wykorzystane w projekcie, które pomogły mi antropologicznie i autoetnograficznie zrozumieć cielesne doświadczenie biegania. 


\section{Dziennik badawczy i literatura piękna}

Dziś dużo mniej eksperymentalne, ale wciąż warte wymienienia są rzecz jasna wyimki z dziennika badawczego, szczególnie te skupiające się na osobie badacza i jego odczuciach. Tekst może mieć charakter bardziej narracyjny, luźniejszy. Pozwala też na oscylowanie między tym, co publiczne, a tym, co intymne - poruszanie się raz na poziomie ogólności, naukowości, by za chwilę pokazać coś bardzo osobistego i prywatnego, co wydaje mi się niezwykle potrzebne i trafne w przypadku życia biegaczki wyczynowej, której codzienność rozgrywa się pomiędzy kontrastującymi ze sobą światami - sceny, jaką jest stadion i kulisów, którymi są treningi i odpoczynek. Dziennik może przyjmować formę zapisków minionych doświadczeń, ale również opowiadań czy poezji (jak w przywołanym na początku tekstu wierszu mojego autorstwa). Dziennik prowadziłam regularnie od początku projektu, jednak odnalazłam również fragmenty z pamiętników z czasów gimnazjalnych i licealnych, które odnosiły się do moich emocji związanych z bieganiem $\mathrm{w}$ tamtym czasie. Teksty czytałam i analizowałam, jednak były mi na tyle dobrze znane, że nie wymagały żadnego dodatkowego kodowania. W toku pracy szybko okazało się, że momentami mocno intymne zapiski z mojego życia dobrze korespondują z wywiadami z biegaczkami, które choć nie opowiadały w taki sam sposób o swojej cielesności jak ja w dzienniku, to oba wymiary sa tożsame. Z drugiej strony ciekawe było dla mnie porównanie transkrypcji wywiadów, czyli języka, którym posługują się biegaczki, z moją własną pisaną formą dzienników i wierszy. Odmienne style okazały się dobrze uzupełniać i doskonale pokazać wielowymiarowość doświadczenia, jakim jest bieg. Warto podkreślić, że porównanie przebiegało w sposób nieoceniający, ponieważ język mówiony, którym posługuję się w filmie autoetnograficznym (o którym piszę w kolejnej części tego tekstu), wcale nie odbiegał od tego, którym posługiwały się moje rozmówczynie.

Autoetnografia pozostawia pole do eksperymentowania wewnątrz samego tekstu poprzez wykorzystywanie różnych gatunków literackich: przeplatanie fragmentów naukowych artystycznymi, sięganie po wiersze i cytaty z literatury pięknej, by zbudować swego rodzaju „pomost” między etnografem a czytelnikiem. Innymi słowy, chodzi o pokazanie dwóch pokrewnych postaw piszącego: „nie tylko ja tak mam” oraz „poprzez literaturę, która mnie porusza, chcę dotrzeć też do ciebie, żebyś mógł lepiej to zrozumieć".

\section{Film i fotografia}

Nieodzownym źródłem informacji stają się dziś media społecznościowe, ze szczególnym wskazaniem na dostępne tam zdjęcia. Opisując cielesne doświadczenia biegaczek, korzystałam zatem z tego, w jaki sposób same kreują swój obraz. Uzupełnieniem były zdjęcia, które wykonywałam podczas zawodów. Poszukiwałam ilustracji do opisów w tekście, charakterystycznych widoków i swoistych "pęknięć".

Rozmowy z koleżankami z bieżni uświadomiły mi jednak, że trudność opowiadania o reakcjach własnego ciała podczas biegu dotyczy również mnie samej. Pomyślałam więc, że powinnam wykonać eksperyment i nakręcić krótki film dokumentujący mój jeden przykładowy trening. Chciałam stworzyć sytuację, w której zbadać można dwa wymiary

\footnotetext{
${ }^{1}$ Film nosi tytuł Ucieleśnione i dostępny jest w serwisie YouTube pod adresem: https://www.youtube.com/watch?v=TuoP6_02MHM\&feature=youtu.be\&app=desktop [dostęp 29 grudnia 2020 r.].
} 
- zewnętrzny, czyli to, jak wizualnie wygląda bieg i jak ciało zmienia się pod jego wpływem (przyspieszony oddech, pot, zmiana techniki biegu wraz $z$ narastającym zmęczeniem lub zmiany tempa itd.), oraz wewnętrzny, czyli to, jak „tu i teraz” opowiadam o swoich cielesnych reakcjach podczas biegu (kiedy czuję się zmęczona, co konkretnie mnie boli, jak opisałabym ten ból itd.). Wydawało mi się, że film autoetnograficzny mógłby być ciekawym uzupełnieniem badań prowadzonych wśród biegaczek profesjonalnych, pokazać nieco inny punkt widzenia albo zilustrować to, o czym trudno było mówić moim rozmówczyniom podczas wywiadu. Nie była to jednak próba odrzucenia czy zminimalizowania niezastąpionej obserwacji uczestniczącej na rzecz filmu etnograficznego (Pacukiewicz 2016), a tym bardziej autoetnograficznego. Chciałam potraktować go jako jeden z "głosów w sprawie”, być może stojący w kontrze do reszty, żeby zniuansować zjawisko i pokazać jego zawiłość. Mój głos autoetnograficzny był inny, bo udzielony niejako post factum - nie trenuję już profesjonalnie, więc mogę spojrzeć na niektóre sprawy z dystansu, bardziej krytycznie, a może przede wszystkim - całkowicie szczerze. Nie oznacza to jednak, że do głosu moich rozmówczyń podchodzę z rezerwą i nieufnością - w ich przypadku chodzi bardziej o nieustającą konieczność utrzymania wewnętrznej motywacji.

Kolejnym argumentem za nakręceniem filmu była, być może pozorna, ale głęboko we mnie tkwiąca chęć stworzenia czegoś prostego $\mathrm{w}$ formie.

Współcześnie film wiąże się nie tyle z abdykacją teoretycznego myślenia, ile raczej próbuje przynajmniej część tych procesów kreowania znaczenia przerzucić na widzów. [...] Można by uznać, że z pomocą filmu wracamy do pierwotnego znaczenia słowa teoria związanego z patrzeniem, a nie tylko konceptualiza- cjami, które są już wynikiem wcześniejszych konceptualizacji. (Sikora 2012: 291)

Projekt postanowiłam zrealizować razem z moją siostrą, która od jakiegoś czasu zajmuje się kręceniem filmów. Jest równocześnie osobą, która obserwuje mnie od wielu lat, także jako biegaczkę, wie zatem, na czym polega uprawianie tego sportu. Z drugiej strony sama nie jest zaangażowana $\mathrm{w}$ badane środowisko, co sprawiło, że na bieganie mogła spojrzeć świeższym niż ja okiem - w tym wypadku przez obiektyw kamery.

Film nakręciłyśmy w gorący czerwcowy sobotni poranek. Ja biegłam, siostra jechała na rowerze z kamerą - podążałyśmy znaną mi trasą na Powiślu. Z początku nieco się stresowałam - byłam nieustająco obserwowana, a nie wiedziałam, jak dokładnie wyglądam. Towarzyszyła mi myśl, że $\mathrm{w}$ pewnym momencie na pewno zacznę się pocić i zrobię się czerwona. Rozmawiałyśmy jednak swobodnie, Weronika zadawała mi ciekawe i chwilami zaskakujące pytania, co było w tym projekcie najważniejsze. Czułam, że przy niej mogę powiedzieć niemalże wszystko i sytuacja nagrywania przestała być $\mathrm{w}$ pewnym momencie problematyczna. Przyszła i chwila zmęczenia, kiedy, mimowolnie, zaczęłam skupiać się już tylko na sobie i swoim ciele: plątał mi się język, ciało było już nieco mniej spięte, ale jednocześnie bardziej skulone, zdyszane i spocone. Szybko okazało się, że mówienie jedynie o bieżących reakcjach cielesnych to za mało - że warto powiedzieć o tym, co dzieje się z organizmem biegaczki w ogóle i o czym myśli się podczas treningu. Postanowiłyśmy nie ukrywać zbyt wiele - nakręciłyśmy pot, zaśliniony język, spocone włosy, zmaskulinizowane ruchy ciała kobiecego, spluwanie na chodnik - nieodłączne elementy każdego treningu biegowego. 
Kilka dni później okazało się, że nie wyczerpałyśmy ciekawych tematów. Usiadłyśmy więc (tym razem na kanapie) i bardzo długo rozmawiałyśmy. Wiedziałam, że chcę powiedzieć także o towarzyszących temu sportowi wyrzeczeniach i trudnościach: konieczności odchudzania się, kompleksach fizycznych i psychicznych, niekiedy trudnych relacjach z trenerami, niespełnionych marzeniach. Prędko doszła kolejna warstwa filmu - nasza siostrzana relacja, w której możemy sobie wszystko powiedzieć bez strachu przed wyśmianiem, pełna wzajemnej troski, ale też otwartej krytyki.

Następnym etapem był montaż, którym zajęła się Weronika. Gotowy film obejrzałam sama w domu. Wiele scen było dla mnie sporym zaskoczeniem - albo dlatego, że spodziewałam się innej selekcji materiału, albo dlatego, że wyglądały inaczej, niż sobie to wyobrażałam. Niemniej jednak mojej siostrze udało się przekazać dokładnie to, co chciałam wyrazić tym filmem.

Gotowy film zaprezentowałam na seminarium magisterskim na uczelni. Konfrontacja z widownią na zajęciach pozwoliła wyodrębnić kilka ciekawych tematów do rozwinięcia w tekście oraz skonfrontowania z cytatami z wywiadów:

- kwestia uprzedmiotowiania zawodniczek przez trenerów;

- ambiwalencja/niejednoznaczność sportu;

- wartości niesione przez sport;

- różnice między organizmem a ciałem;

- powody, dla których sport może zranić, i sposób, w jaki się to odbywa;

- kobiecość w środowisku biegowym - niejednoznaczna wizualność/charakter ciał;

- trener jako głos społeczeństwa;

- istota sukcesu biegowego.
Filmowa autoetnografia zachodzi na trzech poziomach strukturyzacji:

1. na poziomie auto znajduję się ja jako badaczka, antropolożka, chcąca pokazać pewne uniwersalne problemy kobiet biegających profesjonalnie; jednocześnie na poziomie tym znajduje się „ja” biegowe, czyli zawodniczka, która zakończyła karierę, ale sport pozostał jej pasją;

2. w warstwie etno odnajdujemy bliską relację między dwiema bohaterkami filmu - siostrami, która tworzy intymność w filmie;

3. grafia to w tym przypadku nie tekst, ale materia filmowa, która została wybrana w przemyślany sposób; to również świadomość istnienia oceniającego widza.

Uzupełnieniem tekstu stał się zatem film autoetnograficzny, który dodał tym samym nieco performatywności samemu projektowi.

\section{Zakończenie}

Dzisiejsze zainteresowanie nauk społecznych tematami związanymi z cielesnością nie powinno się ograniczać do biernej obserwacji oraz realizowania wywiadów. Odkąd w antropologii dowartościowano obecność badacza, nieuniknionym jest zawarcie w tekście osoby jego samego. Metodą, która daje tego typu narzędzia, jest autoetnografia, oferująca różne podejścia badawcze (ewokatywne lub analityczne, ale również uzupełniająco performatywne oraz kolaboratywne), w zależności od potrzeby i tematu. Co więcej, metodologia ta wydaje się szczególnie trafna w przypadku badań nad cielesnym wymiarem sportu - daje bowiem nowe możliwości konceptualizacji trudnych do opisania tradycyjny- 
mi metodami aktywności ruchowych. Własne doświadczenie badacza staje się tutaj kolejnym głosem, który może wnieść coś nowego i zaskakującego do projektu. Autoetnografia, stawiająca na empatyzację i kontakt z wrażliwym czytelnikiem, dowartościowuje też techniki wspomagające, takie jak: film, fotografia, zapiski, poezja, performans, instalacja czy literatura piękna.

Sport to doświadczenie cielesne, o którym nie sposób mówić, pomijając własne przeżycia i emocje. Taki opis wcale nie musi być nienaukowy - wręcz przeciwnie, może przynieść niespodziewane wnioski.

\section{Bibliografia}

Anderson Leon (2014) Autoetnografia analityczna. „Przegląd Socjologii Jakościowej", t. 10, nr 3, s. 144-166.

Chang Heewon, Ngunjiri Faith Wambura, Hernandez Kathy-Ann C. (2013) Collaborative Autoethnography (Developing Qualitative Inquiry). London: Routledge.

Domańska Ewa (2007) "Zwrot performatywny” we współczesnej humanistyce. „Teksty Drugie”, nr 5, s. 48-61.

Ellis Carolyn, Bochner Arthur (2000) Autoethnography, personal narrative, reflexivity: Researcher as subject [w:] Norman K. Denzin, Yvonna S. Lincoln, eds., Handbook of Qualitative Research. Los Angeles: Sage Publications, s. 733-768.

Garncarek Emilia (2010) Kobiece ciało jako przedmiot kontroli społecznej. „Przegląd Socjologiczny”, t. 59, nr 3, s. 55-69.

Hastrup Kirsten (2008) Droga do antropologii. Między doświadczeniem a teoria. Kraków: Wydawnictwo Uniwersytetu Jagiellońskiego.

Hockey John (2006) Sensing the run: The senses and distance running. „Senses \& Society”, vol. 2, no. 1, s. 183-202.
Metodę autoetnograficzną zastosowałam w badaniach biegaczek wyczynowych, jednak widzę olbrzymi potencjał tego podejścia również w przypadku innych pól badawczych. Moją drugą pracę magisterską zatytułowaną Walka o widzialność. Figura "stawania się artystka" na Akademii Sztuk Pięknych, obronioną na ASP w Warszawie na Wydziale Zarządzania Kulturą Wizualną, osadziłam częściowo w metodologii autoetnograficznej, opisując moje doświadczenia jako studentki tej uczelni. Autoetnografia wydaje mi się zresztą trafna $\mathrm{w}$ odniesieniu do tematów z pogranicza etnologii i sztuki, gdzie badacz staje się często jednocześnie artystą.

Jakubowska Honorata (2012) Sport z perspektywy płci. Dyskusje o nierówności, tożsamości i odkrytym/ukrytym ciele [w:] Monika Kozioł, Delfina Piekarska, Maria Anna Potocka, red., Sport w sztuce. Kraków: Muzeum Sztuki Współczesnej w Krakowie, s. 80-95.

Jakubowska Honorata (2015) Wiedza pozadyskursywna i sposoby jej badania na przykładzie przekazywania $i$ nabywania sportowych umiejętności. „Studia Socjologiczne”, nr 3 (218), s. 173-191.

Kacperczyk Anna (2014) Autoetnografia - technika, metoda, nowy paradygmat? O metodologicznym statusie autoetnografii. „Przegląd Socjologii Jakościowej", t. 10, nr 3, s. 32-74.

Kafar Marcin (2014) Wokół humanizacji nauki - znaki, tropy, konteksty. „Przegląd Socjologii Jakościowej”, t. 10, nr 3, s. 16-31.

Lefebvre Henri (1991) The Production of Space. Oxford: Blackwell.

Malinowski Bronisław (2008) Dziennik w ścistym znaczeniu tego wyrazu. Kraków: Wydawnictwo Literackie.

McMahon Jenny (2011) Body work - Regulation of a swimmer body: an authoethnography from an Australian elite swimmer. "Sport Education and Society", vol. 16, no. 1, s. 35-50. 
Pacukiewicz Marek (2016) Refleksy w obiektywie. Mitologika filmu etnograficznego [w:] Jakub Dziewit, Małgorzata Kołodziej, Adam Pisarek, red., Patrzenie i widzenie w kontekstach kulturoznawczych. Katowice: Wydawnictwo Grupa Kulturalna.pl, s. 29-43.

Samudra Jaida Kim (2008) Memory in our body: Thick participation and the translation of kinesthetic experience. "American Ethnologist", vol. 35, no. 4, s. 665-681.

Sikora Sławomir (2012) Filmy i paradoksy wizualności. Praktykowanie antropologii. Warszawa: DiG, Instytut Etnologii i Antropologii Kulturowej Uniwersytetu Warszawskiego.
Szyma Karolina (2018) _63. Dostępny w Internecie: ‘https:// www.instagram.com/p/BoeeHOPllnd/>.

Szyma Karolina (2019) Ucieleśnione w ruchu. Polskie biegaczki wyczynowe w perspektywie antropologicznej. Warszawa: Wydawnictwa Uniwersytetu Warszawskiego.

Taussig Michael (1992) The Nervous System. London: Routledge.

Wala Katarzyna (2012) [Nie] potrafię gotować! Dostępny w Internecie: https://stosowana.wordpress.com/2012/05/09/nie-potrafie-gotowac [dostęp 16 sierpnia 2017 r.].

\section{Cytowanie}

Szyma-Ziembińska Karolina (2021) "Ja, ucieleśniona w ruchu”, czyli o biegowej drodze z autoetnografia. "Przegląd Socjologii Jakościowej", t. 17, nr 1, s. 42-55 [dostęp dzień, miesiąc, rok]. Dostępny w Internecie: ‘www.przegladsocjologiijakosciowej.org〉. DOI: http://dx.doi.org/10.18778/1733-8069.17.1.04

\section{My-Self, Embodied in Motion: About Running Road with Autoethnography}

Abstract: The article shows how autoethnography can enrich research on sport. As a former competitive runner, the author describes how she has used tools such as autoethnographical movie, photography, or research diary for a complex anthropological illustration of the running experience. The researcher observer the expanding scope of ways in which this technique can be applied to a variety of research topics, with a special consideration of the anthropology of body. She also tackles the problem of the linguistic incommunicability of experiencing the body in sport as well as she suggests solutions. The article is based on the book Embodied in Motion: Polish Female Professional Runners in Anthropological Perspective, but also supplemented with new observations. As its author writes, "For me, autoethnography is valuable also in that it is an interesting engagement between the interlocutors and the researcher, during which an exchange of experiences and opinions takes place. It is a certain work on the relationship. This way, both parties expose themselves; both risk something, and this can result in interesting conclusions" [the editor's translation].

Keywords: anthropology of sport, anthropology of body, embodiment, autoethnography, running 